\title{
Persistence of Idaho fescue on degraded range- lands: Adaptation to defoliation or tolerance
}

\author{
RAYMOND G. JAINDL, PAUL DOESCHER, RICHARD F. MILLER, LEE E. \\ EDDLEMAN
}

\begin{abstract}
Authors are research associate, associate professor, and professors, Rangeland Resources, Oregan State University, Corvallis 97331; Miller is stationed at Eastern Oregon Agricultural Research Center, Oregon State University, Burns 97720. The Eastern Oregon Agricultural Research Center, including the Northern Great Basin Experimental Range, is jointly operated by the Oregon Agricultural Experiment Station and USDA Agricultural Research Service.
\end{abstract}

\begin{abstract}
Rangelands with histories of overgrazing are frequently depauperate of native grasses. Occasionally, remnant native grasses are found surviving in these areas. We hypothesized that these survivors have responded to livestock grazing, over the past 110 years, through development of genetically based ecotypes that are more tolerant of defoliation than populations protected from heavy use by domestic livestock. Transplanted individuals of a native grass, Idaho fescue (Festuca idahoensis Elmer), from heavily grazed and ungrazed rangelands were compared. Gardens were established in central Oregon at the Central Oregon Agricultural Experiment Station and in eastern Oregon at the Northern Great Basin Experimental Range. Plants were defoliated during the vegetative, boot, and anthesis stages in 1990 and 1991 and subsequent growth evaluated. Parameters measured were end of growing season basal area, relative biomass production, and height and phenology at about biweekly intervals. Grazing history had no consistent effect on Idaho fescue response to defoliation. There were, however, differences between the protected and grazed collections from central Oregon in that the protected population averaged greater height and relative growth than those from the grazed areas even with defoliation. While the limited number of ungrazed sources in this region limits broad speculation, these results suggest Idaho fescue survival in heavily grazed areas might be the result of differences in growth form rather than overcompensation or variation in time of phenologic development. Results also suggest that Idaho fescue from this region may elicit some grazing tolerance despite evolving historically with few large herbivores.
\end{abstract}

Key Words: relative growth, Festuca idahoensis, compensatory gain, genetic variation

On many areas of the Intermountain West, rangelands had been subjected to abusive land management practices from at least 1880 to about 1940 and are still subjected to competition and invasion by alien weeds. Effects of these changes include a decline in productivity, aesthetic appeal, and diversity. Efforts to reestablish perennial grasses on degraded rangelands often involve use of herbicides or mechanical manipulations, and seeding of introduced perennial species that effectively compete with weeds (Vallentine 1989). There has been limited success in reseeding efforts involving late-

\footnotetext{
The authors would like to thank Mike Borman, research scientist, BLM Pacific Forest and Basin Rangeland Systems Cooperative Research Unit; William Krueger, professor and department head, Department of Rangeland Resources, Oregon State University; Mike McInnis, associate professor, Oregon State University Agricultural Program, Eastern Oregon State College; and several anonymous reviewers for reviewing and providing valuable suggestions for improving this manuscript.

This material is based upon work supported by the Cooperative State Research

Service, USDA, under Agreement 88-38300-3623. Submitted as Technical Paper

10,126, Oregon Agriculture Experiment Station, Oregon State University 97331.

Manuscript accepted 3 Sept. 1993.
}

seral native species (Wasser 1982).

Native perennials have not persisted on many areas of the Intermountain West because of sensitivity to defoliation, inability to compete as seedlings, and poor regeneration ability (Harris and Wilson 1970, Harris 1977, Mack and Thompson 1982). In areas such as the Great Plains of North America (Detling and Painter 1983) and the Serengeti Plains of Africa (McNaughton 1979, 1984) in which herbivory has been a major selective force on vegetation, grasses have evolved characteristics that enable them to tolerate heavy grazing. Among these are a more prostrate growth form, rapid reestablishment of tillers, and compensatory gain although the latter is considered controverisal (Belsky 1986). In contrast, the steppe vegetation of the Intermountain West was thought not to have had the same large herbivore impact and thus the vegetation is genetically less tolerant to high levels of herbivory (Mack and Thompson 1982). Yet, we have observed late-seral perennial bunchgrasses persisting at low densities on certain sites in central and eastern Oregon with a history of high levels of herbivory from 1880 to the $1950 \mathrm{~s}$. We hypothesized that overgrazing by livestock, over 70 or more years, caused expression of a genetically based ecotypic variation within native grasses such that grazed populations are more tolerant of defoliation than populations protected from overgrazing by domestic livestock. In this experiment, we assessed growth patterns and response to defoliation of remnant populations of Idaho fescue (Festuca idahoensis Elmer) collected from central and eastern Oregon to determine if these individuals exhibit morphological and physiological attributes that enable them to tolerate defoliation.

Idaho fescue was chosen for study because of its importance as forage in this area and its ability to form ecotypes in response to environmental conditions (Tisdale 1961, Stocker 1975, Doescher et al. 1985). If our basic hypothesis proves correct, then the success of reintroduction of native grasses to the Intermountain steppe could be enhanced by using seed gathered from populations exposed to a long history of heavy grazing and are genetically adapted to grazing by domestic livestock.

\section{Methods}

Experimentation was conducted concurrently at 2 locations using plant material transplanted from local populations. One common garden was established at the Central Oregon Agricultural Experiment Station $12 \mathrm{~km}$ west of Prineville, Ore., in the central Oregon sagebrush steppe at $975-m$ elevation. Mean annual precipitation at the nearest recording station, Prineville (elevation $870 \mathrm{~m}$ ), is $254 \mathrm{~mm}$ with $80 \%$ of the precipitation occurring between November and June as both snow and rain. Mean daily temperatures are 1 and $16^{\circ} \mathrm{C}$ for the winter and summer, respectively. Soils 
in this area are gravelly sandy loam to loamy sand with $0-2 \%$ slopes (Mayko and Smith 1966).

Eastern Oregon populations of Idaho fescue were established in a common garden at the Northern Great Basin Experimental Range (formerly the Squaw Butte Experimental Range) $67 \mathrm{~km}$ west of Burns, Ore., in the sagebrush steppe at $1,415-\mathrm{m}$ elevation. The 37-year mean annual precipitation is $284 \mathrm{~mm}$. Most precipitation occurs between November and May as snow and rain. Mean daily temperatures are -0.6 and $17.6^{\circ} \mathrm{C}$ for the winter and summer, respectively. The soils are loamy alluvium weathered from rhyolite, andesite, and basalt bedrock. These soils are on broad stream floodplains and terraces with $0-2 \%$ slopes (Lentz and Simonson 1986).

Plant materials at each common garden represented regional populations of Idaho fescue. Collections were from areas historically heavily grazed $(G)$ and were compared to a collection from the respective geographic area (central or eastern Oregon) which historically has been protected from grazing (P). Plants from the grazed areas were not selected if in safe sites unavailable to grazing animals. The protected collection for the central Oregon study was from an area which was unavailable to livestock because of topography (Driscoll 1964). The protected collection for eastern Oregon was from within a livestock exclosure established in 1938 that was heavily grazed before 1938. Collections for each garden were from range sites that were as similar as possible. Limited replication of protected populations is unfortunate but unavoidable because of the limited undisturbed relict areas in the regions of this study.

Plant materials for the central Oregon garden were from mountain big sagebrush (Artemisia tridentata Nutt. spp. vaseyana (Rydb.) J. Bovin) sites with grazed areas being invaded or dominated by western juniper (Juniperus occidentalis Hook). Elevation of the collection sites ranged between 730 and $1,220 \mathrm{~m}$. Collection sites were within $45 \mathrm{~km}$ of the garden study area. Site specific characteristics were:

C-P-The Island Research Natural Area has had negligible use by

livestock because of lack of surface water and accessibility. The only known instance of planned livestock grazing was in 1922 and 1928 when bands of sheep were driven into the area (Driscoll 1964).

C-G1 and C-G2-Combe's Flat and Marrow Ranch, respectively, are private land at present moderately grazed by cattle but heavily grazed by sheep in the early 1900 s.

C-G3 and C-G4-Lithgow Spring and Lone Pine Flat, respectively, are on the USDA Forest Service (USFS) Crooked River National Grassland. Much of this area was homesteaded and then deserted when crops failed. Lands not farmed were heavily grazed by sheep in the early 1900 s and are now moderately grazed by cattle under management designed by the USFS.

Plant materials for the eastern Oregon garden were from Wyoming big sagebrush (Artemisia tridentata spp. wyomingensis (Beetle \& A. Young) Welsh) sites with the exception of the Brothers collection, which was from a mountain big sagebrush ("xericensis") site (Hironaka et al. 1983). Elevation of the collection sites ranged between 1,370 and $1,400 \mathrm{~m}$. Site specific characteristics were:

E-P and E-G 1-Northern Great Basin Experimental Range exclosure and outside the exclosure, respectively. Grazing has been excluded inside the exclosure since 1938 while outside the exclosure grazing by cattle has continued under management designed by the USDA Northern Great Basin Agricultural Experiment Station. The entire area was heavily grazed by sheep in the early 1900s.

E-G2-Glass Butte is $30 \mathrm{~km}$ west of the common garden site. E-G3-Brothers is $75 \mathrm{~km}$ west of the common garden site. The area was homesteaded and plowed in the early 1900 s. E-G4-Gravel Pit Road-10 km north of the common garden site.

Although a documented grazing history for E-G2, E-G3, and E-G4 sites was not available, grazing use by cattle and sheep was assumed historically heavy before administration of management designed by the U.S. Bureau of Land Management because of the low abundance of perennial grasses and the historic high levels of grazing in central and eastern Oregon (Eddleman 1989).

Plant units of about the same size, $12-\mathrm{cm} \times 12-\mathrm{cm}$, were transplanted during May 1989 and allowed to establish until spring 1990. Additional plants were transplanted in the common garden to serve as replacements for those not surviving transplanting. Plants were arranged in a completely randomized design with 50 plants from each location planted $1 \mathrm{~m}$ apart in a $16-\mathrm{m} \times 16-\mathrm{m}$ grid. The 6 extra spots were filled in with extra plants to complete the grid, but these were not used in the study. To provide uniform root competition for the border rows and to isolate the garden from the surrounding area, an additional row of Idaho fescue was established around the perimeter of the grid. Weeds were controlled by hand hoeing throughout the growing season. To enhance establishment, the central Oregon site was irrigated weekly from May to June 1989, and the eastern Oregon site watered 4 times during the summer. Limited over-winter mortality was observed at either location in spring 1991 before defoliation treatment. Death loss after treatments were applied was limited and no difference due to collection or defoliation at either garden was observed.

The study was conducted in 1990 and 1991. Before growth initiation in the spring of the years of study (March 1990 and 1991), all plants were clipped $5 \mathrm{~cm}$ above the ground to reduce the confounding influence of different quantities of standing litter. Plants were randomly assigned in the spring of 1990 to 1 of 4 defoliation treatments with 10 replicates per collection per treatment. Defoliation treatments were standardized on the basis of phenology, thus defoliation date varied by site and year (Fig. 1). Defoliation treatments were: (1) no clipping; (2) clipping when plants were in the 3-4 leaf stage (vegetative stage); (3) clipping when plants were beginning to exert inflorescences (boot stage); and (4) clipping when plants were in anthesis (complete inflores-

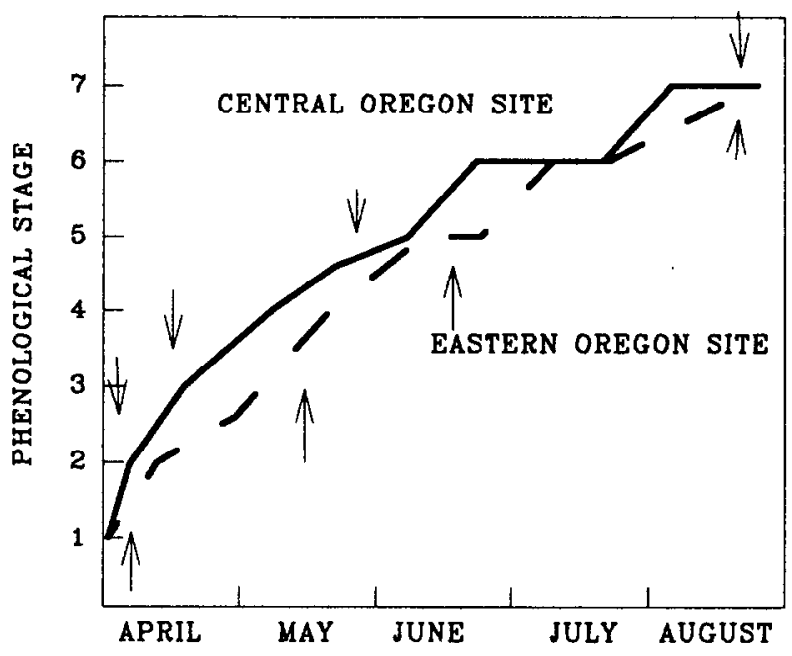

Fig. 1. Idaho fescue growth cycle during growing season at cental and eastern Oregon sites. Arrows indicate approximate clipping dates during the 2 years of this study (Central Oregon dates were 4/9,4/22,5/10, and $9 / 8$ in 1990, and 4/13,4/26,5/7, and $8 / 20$ in 1991; Eastern Oregon dates were $4 / 13,5 / 11,6 / 10$, and $8 / 30$ in 1990 , and $4 / 24,5 / 5,6 / 7$, and $8 / 30$ in 1991) (See Table 1 for a description of phenological code). 
cence emergence). Plants were clipped to a height of $5 \mathrm{~cm}$ above ground level. Material clipped for each treatment was dried for 48 hours at $50^{\circ} \mathrm{C}$ and weighed to estimate current year's standing crop at the time of clipping. All plants were defoliated to a $5-\mathrm{cm}$ height in mid-August to determine regrowth for the clipping treatments and total growth of the control.

Basal area was measured on the defoliation day for the respective treatment plants and at the end of the growing season for all treatments. Basal area measurements were made by wrapping a copper wire around the tussock base after clipping and then pulling the wire upward vertically. The wire maintained the shape of the base throughout the operation. The resulting model of the tussock's perimeter was traced on heavy-weight paper, cut out, and measured on a LI-COR 3100 area meter. At both locations, basal area expansion of individual plants was accompanied by death of the interior portions of the plants. The live portion in 1990 and 1991 and the total basal area including the dead centers in 1991 were evaluated for response to defoliation and collection. Similar patterns were observed in results of analysis of the live portion and total basal area, so only total basal area is reported.

Biomass was standardized on a basal area basis (i.e., relative biomass = plant biomass $/$ basal area) for evaluating relative growth as a function of collection and treatment. Current year's net relative production was estimated by adding relative biomass present at the first clipping to that obtained in August. Relative growth of collections between phenological stages was estimated by the difference in the mean relative biomass between 2 defoliation dates (relative growth $=$ mean relative biomass of a clipping treatment minus mean relative biomass of the previous clipping treatment).

During 1990 only, plant growth was monitored about biweekly throughout the growing season (30 March-20 August). Parameters measured were height of the tallest culmed tiller after culms became apparent and stage of phenology of plants following an adaptation of scoring developed by Dragt (1985) (Table 1).

Table 1. Phenological stage following an adaption of scoring developed by Dragt (1985).

\begin{tabular}{cl}
\hline \hline Score & Phenological stage \\
\hline 1 & Vegetative stage, no internode elongation \\
2 & Internode elongation, before inflorescence emergence \\
3 & Inflorescence emergence $<50 \%$; apical buds above $5 \mathrm{~cm}$ clipping \\
& height \\
4 & Inflorescence emergence $>50 \%$ \\
5 & Anthesis \\
6 & Mature flowers \\
7 & Seed shatter \\
8 & Mature foliage \\
9 & Fall regrowth \\
\hline
\end{tabular}

Basal area at the end of each growing season and relative annual production were evaluated separately for each garden using analysis of variance (ANOVA) in a completely randomized 3 factor (collection, defoliation treatment, year) design with repeated measures on collection and defoliation treatment (Winer et al. 1991). Phenological stage and height were analyzed for defoliation treatments and gardens using ANOVA for a completely randomized 2 factor (collection, time) design with repeated measures on collection (Winer et al. 1991). Differences in seasonal relative growth among collections were analyzed separately for each garden and phenological stage in a completely randomized block design with years as blocks. When the ANOVA showed significant F values, differences were separated using Waller and Duncan's BLSD mean separation procedure (Steel and Torrie 1980). Only significant differences are reported in the text $(\alpha=0.05)$. No analysis compar- ing the 2 gardens were made.

\section{Results}

\section{Phenology and Height}

In 1990 at the central Oregon garden, no consistent differences in phenology were observed among collections or as a result of defoliation. At eastern Oregon, E-P and E-G3 developed slower during a period of the growing season when compared to the other collections. Development of E-G3 was slower at the beginning of the season (April to 9 June), but was not different from the other grazed populations after 9 June 1990. Development of E-P was slowed from 22 June to $20 \mathrm{July}$. This was not related to the defoliation treatments so cause for this difference is not known.

Significant differences in plant height at the central Oregon location were found among collections (Fig. 2). The relative order of response was C-P>C-G1, C-G3, and C-G4>C-G2. For the eastern Oregon collections, a significant height difference occurred as a collection $X$ time interaction with E-G3 significantly taller than E-P, E-G1, and E-G2 on the last 2 sampling dates. Differences among defoliated plants were similar to those observed among undefoliated plants.
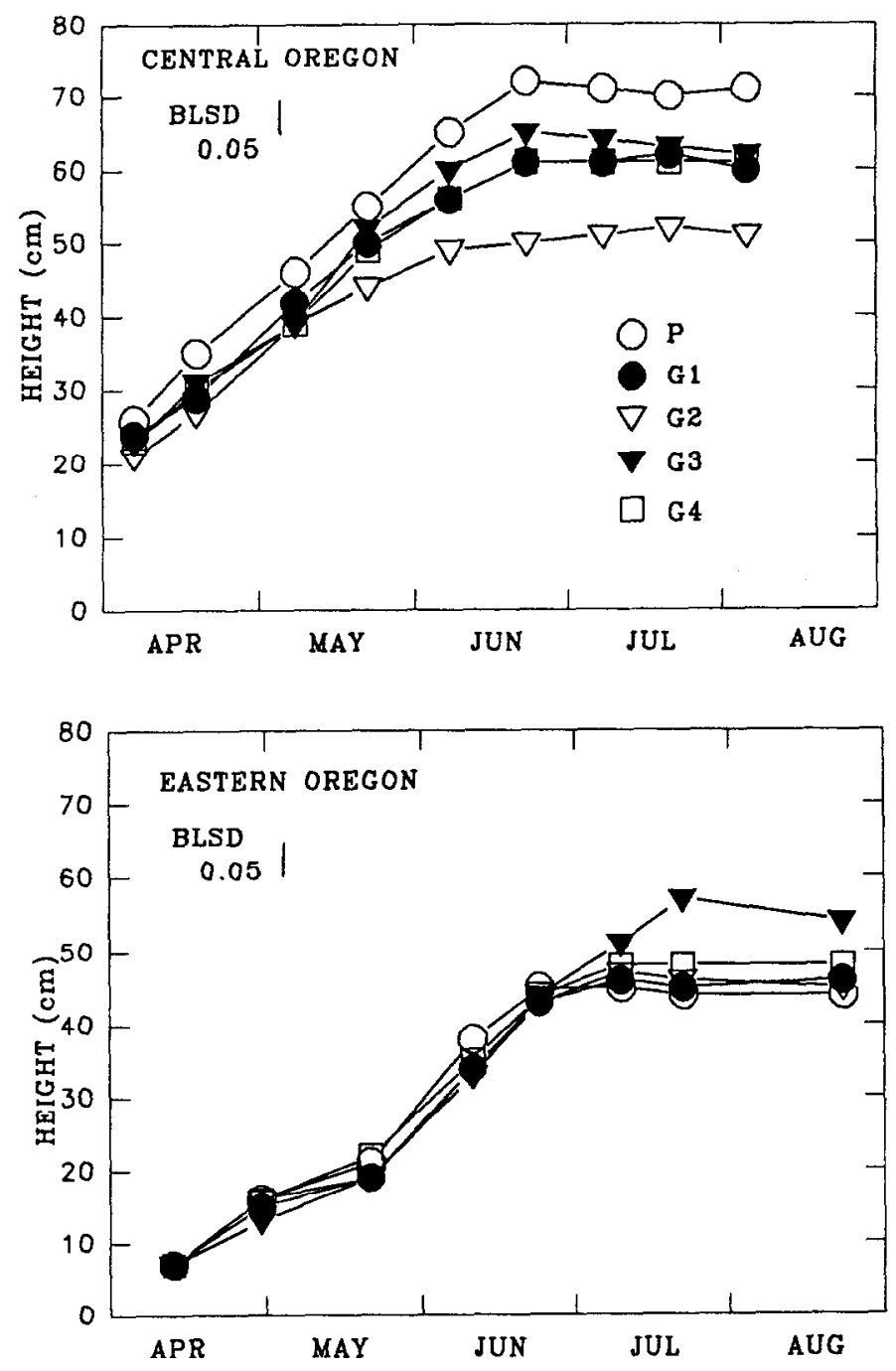

Fig. 2. Height of undefoliated plants during the 1990 growing season. Collections are of Idaho fescue from historically ungrazed $(P)$ and grazed sites (G1-4) from eastern and central Oregon and grown in common gardens in their respective geographic area. 


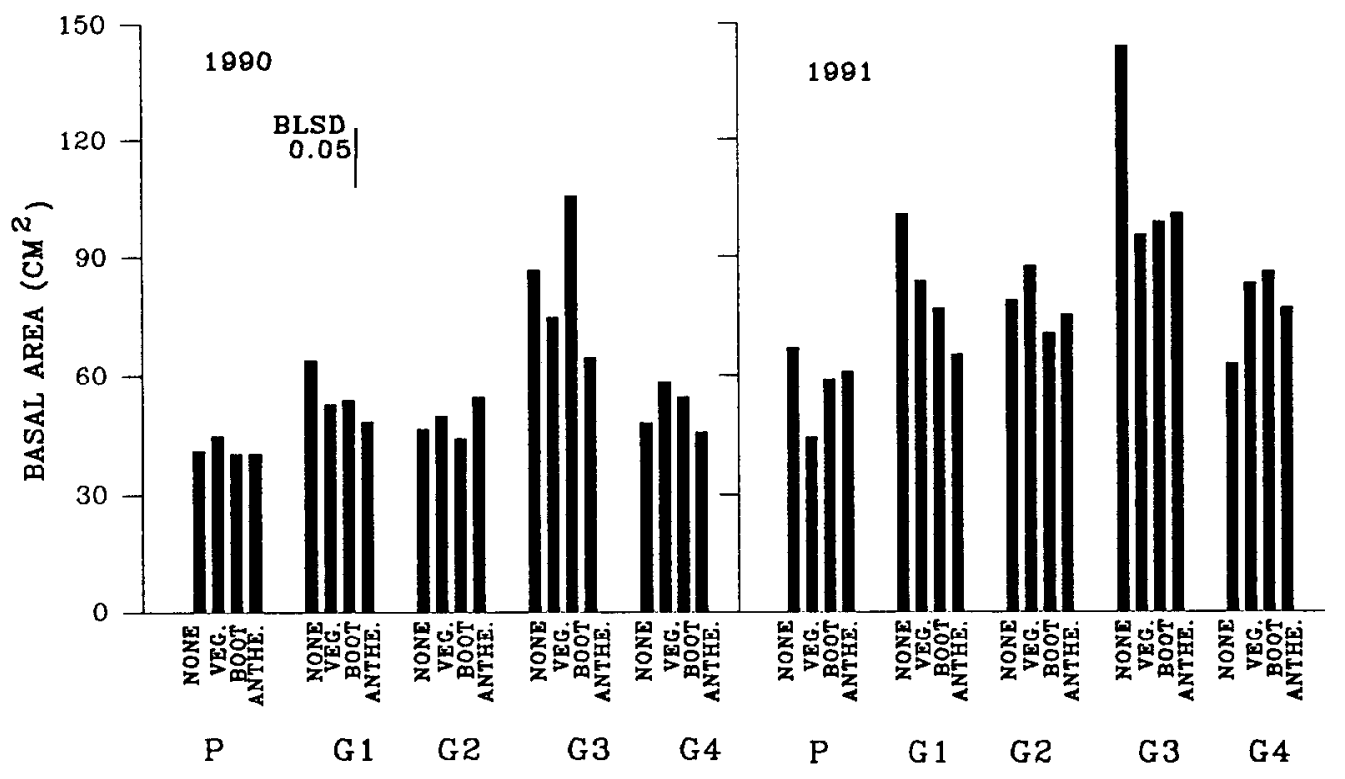

Fig. 3. Mean basal area measured in August 1990 and 1991 of Idaho fescue collections from eastern Oregon grown in a common garden. Plants were defoliated either during the vegetative boot, or anthesis stage or not at all. Collection areas represent sites historically ungrazed (P) or subject to heavy grazing for a large part of the 1900s (G1-4).

\section{Basal Area}

At central Oregon the only significant effect on total basal area, other than year, was a collection $X$ year interaction $(P<0.05)$ (Table 2). Average basal area of C-P was smaller than 3 of the 4 grazed populations in 1990. By August 1991 total basal areas increased 15 to $45 \%$ within each collection and there was no significant difference in basal area due to collection, defoliation, or their interaction.

Table 2. Mean basal area measured in August 1990 and 1991 of Idaho fescue collections from central Oregon grown in a common garden. Collection areas represent sites historically ungrazed $(P)$ or subject to heavy grazing for a large part of the 1900s (G1-4).

\begin{tabular}{|c|c|c|c|c|c|c|}
\hline & \multicolumn{6}{|c|}{ Collection } \\
\hline & $\mathbf{P}$ & G1 & G2 & G3 & G4 & BLSD \\
\hline & 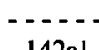 & . . - - & $-\left(\mathrm{cm}^{2}\right)-$ & & 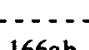 & \\
\hline $\begin{array}{l}1990 \\
1991\end{array}$ & $\begin{array}{l}142 a^{1} \\
213\end{array}$ & $\begin{array}{l}186 \mathrm{cb} \\
232\end{array}$ & $\begin{array}{l}195 \mathrm{cb} \\
229\end{array}$ & $\begin{array}{l}192 \mathrm{c} \\
217\end{array}$ & $\begin{array}{l}166 \mathrm{ab} \\
214\end{array}$ & $\begin{array}{c}25 \\
\mathrm{NA}^{2}\end{array}$ \\
\hline
\end{tabular}

'Means in a row not sharing a common letter differ $(p<0.05)$.

${ }^{2}$ Failure in $\mathrm{T}$ computation because $\mathrm{F}$ value too small $(\mathrm{SE}=15.4)$.

Eastern Oregon transplants were from material that contained a large portion of dead tillers in the transplanted plugs. Thus, basal areas declined from that of the original transplant plug by the initiation of the treatments. During the study period, there were significant differences $(p<0.01)$ among collections, years, and collections $\times$ defoliation $\times$ year interaction (Fig. 3). Although there was some indication that differences occurred as a 3 way interaction, no biologically significant pattern in relation to our hypothesis could be determined in the 3 way interaction. Collection differences were also highly significant $(p<0.01)$ with E-P $<\mathrm{E}-\mathrm{G} 1, \mathrm{E}-\mathrm{G} 2$, E-G4<E-G3 $\left(50,69,64,65\right.$, and $96 \mathrm{~cm}^{2}$ basal area, respectively. BLSD $=14.3$ ).

\section{Relative Production}

For relative annual production ( $\mathrm{g} \mathrm{cm}^{-2}$ basal area) significant year $\times$ defoliation and year $\times$ collection interactions were detected for the central Oregon garden and a year $\times$ collection $X$ defoliation interaction was detected for the eastern Oregon garden. At the central Oregon site, relative annual growth for C-P was greater than all C-G collections (Table 3). At the Eastern Oregon site, no biologically significant pattern in relation to our hypothesis could be determined in the 3 way interaction. Highly significant $(p<0.01)$

Table 3. Mean relative annual production by August 1990 and 1991 of Idaho fescue collections from central Oregon grown in a common garden. Plants were defoliated either during the vegetative, boot, or anthesis stage or not at all. Collection areas represent sites historically ungrazed (P) or subject to heavy grazing for a large part of the 1900 s (G1-4).

\begin{tabular}{|c|c|c|c|c|c|c|}
\hline \multirow[b]{2}{*}{ year } & \multicolumn{6}{|c|}{ Collection } \\
\hline & $\mathbf{P}$ & G1 & G2 & G3 & G4 & BLSD \\
\hline \multirow[t]{3}{*}{$\begin{array}{l}1990 \\
1991\end{array}$} & $\begin{array}{l}-26 \mathrm{a}^{1} \\
0.36 \mathrm{a}\end{array}$ & $\begin{array}{l}-1 \mathrm{~g} \mathrm{~cm} \\
0.18 \mathrm{c} \\
0.21 \mathrm{bc}\end{array}$ & $\begin{array}{c}-2 \text { basal } \\
0.20 \mathrm{bc} \\
0.19 \mathrm{c}\end{array}$ & $\begin{array}{l}0.17 \mathrm{c} \\
0.20 \mathrm{bc}\end{array}$ & $\begin{array}{l}0.22 \mathrm{~b} \\
0.24 \mathrm{~b}\end{array}$ & $\begin{array}{l}0.026 \\
0.041\end{array}$ \\
\hline & \multicolumn{6}{|c|}{ Defoliation } \\
\hline & None & Vegetative & Boot & Anthesis & BLSD & \\
\hline $\begin{array}{l}1990 \\
1991\end{array}$ & $\begin{array}{l}\ldots .20 \\
0.20 \mathrm{~b}\end{array}$ & $\begin{array}{l}0 .(\mathrm{g} \mathrm{cm} \\
0.20 \\
0.22 \mathrm{~b}\end{array}$ & $\begin{array}{l}-2 \text { basal } \\
0.22 \\
0.26\end{array}$ & $\begin{array}{l}\text { ea) }-21 \\
0.28 \mathrm{a}\end{array}$ & $\begin{array}{c}0 . \\
\mathrm{NA}^{2} \\
0.039\end{array}$ & \\
\hline
\end{tabular}

'Means in a row not sharing a common letter differ $(p<0.05)$.

${ }^{2}$ Failure in $T$ computation because $F$ value too small ( $\mathrm{SE}=0.014$ ).

year $\times$ collection and year $\times$ defoliation interactions, that also occurred, indicate that relative annual growth for E-G2 and 3 was significantly less than E-G1 in 1990 and E-G3 was significantly less than all of the other eastern Oregon collections in 1991 (Fig. 4).

The only significant difference in relative production among collections in central Oregon occurred between the vegetative to boot stage (Table 4) though numerical differences were greater during other growth stages. During the vegetative to boot stage C-P, C-G1, and C-G4 had higher relative growth rates than C-G2 and C-G3 collections. At eastern Oregon there was no significant difference in seasonal growth through August due to collection.

\section{Discussion}

This study provided opportunities to evaluate within-species diver- 


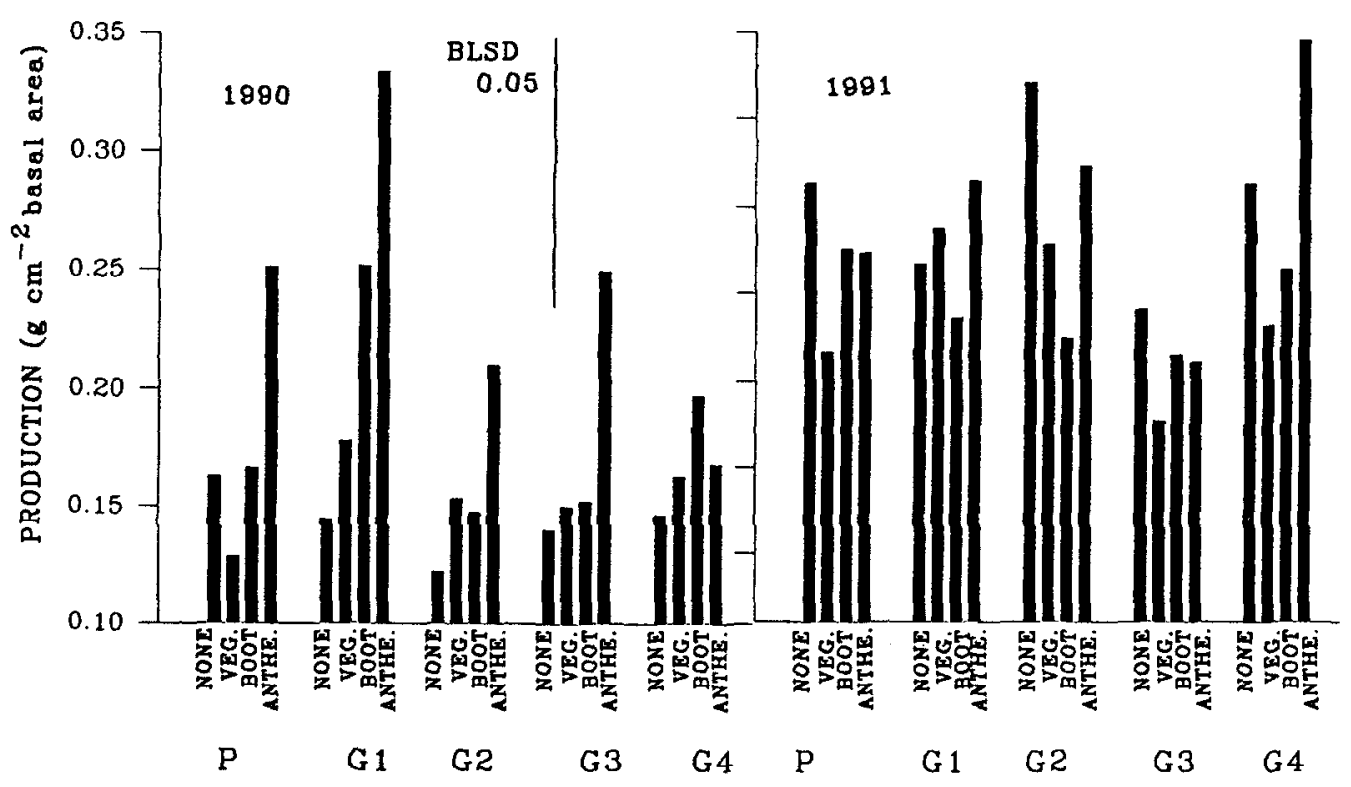

Fig. 4. Mean relative annual production by August 1990 and 1991 of Idaho fescue collections from eastern Oregon grown in a common garden. Plants were defoliated either during the vegetative, boot, or anthesis stage or not at all. Collection areas represent sites historically ungrazed (P) or subject 0 heavy grazing for a large part of the 1900 s (G1-4).

Table 4. Relative change in production during vegetative growth stage, vegetative to boot stage, boot to anthesis stage, and anthesis to dormant stage of development of collections of Idaho fescue from eastern and central Oregon and grown in common gardens in their respective geographic area. Collections are from historically ungrazed (P) and heavily grazed sites (G1-4). Values are means of the 1990 and 1991 growth years.

\begin{tabular}{|c|c|c|c|c|c|c|}
\hline \multirow{2}{*}{$\begin{array}{l}\text { Central Oregon } \\
\text { Period }\end{array}$} & \multicolumn{6}{|c|}{ Collection } \\
\hline & $\mathbf{P}$ & G1 & $\mathrm{G} 2$ & G3 & G4 & S.E. \\
\hline $\begin{array}{l}\text { Vegetative stage } \\
\text { Vegetative to boot } \\
\text { Boot to anthesis } \\
\text { Anthesis to dormant }\end{array}$ & $\begin{array}{l}0.09 \\
0.08 \mathrm{a}^{2} \\
0.10 \\
0.00\end{array}$ & $\begin{array}{l}-(\mathrm{g} \mathrm{cr} \\
0.06 \\
0.08 \mathrm{a} \\
0.00 \\
0.06\end{array}$ & $\begin{array}{c}-2 \text { basal } \\
0.06 \\
0.05 b \\
0.07 \\
-0.01\end{array}$ & $\begin{array}{l}0.05 \\
0.04 b \\
0.05 \\
0.05\end{array}$ & $\begin{array}{l}0.05 \\
0.08 \mathrm{a} \\
0.07 \\
0.01\end{array}$ & $\begin{array}{l}0.02^{1} \\
0.01^{3} \\
0.02^{1} \\
0.05^{1}\end{array}$ \\
\hline \multicolumn{6}{|l|}{ Eastern Oregon } & Collection \\
\hline Period & $\mathbf{P}$ & G1 & G2 & G3 & G4 & S.E. \\
\hline $\begin{array}{l}\text { Vegetative stage } \\
\text { Vegetative to boot } \\
\text { Boot to anthesis } \\
\text { Anthesis to dormant }\end{array}$ & $\begin{array}{l}\ldots . \\
0.03 \\
0.06 \\
0.10 \\
0.04\end{array}$ & $\begin{array}{c}--(\mathrm{g} \mathrm{cr} \\
0.04 \\
0.06 \\
0.14 \\
-0.06\end{array}$ & $\begin{array}{c}-2 \text { basal } \\
0.04 \\
0.02 \\
0.11 \\
0.04\end{array}$ & $\begin{array}{l}\text { area) - } \\
0.02 \\
0.05 \\
0.09 \\
0.00\end{array}$ & $\begin{array}{l}0.04 \\
0.04 \\
0.10 \\
0.02\end{array}$ & $\begin{array}{l}0.01^{1} \\
0.02^{1} \\
0.05^{1} \\
0.05^{1}\end{array}$ \\
\hline
\end{tabular}

1Failure in $\mathrm{T}$ computation because $\mathrm{f}$ value too small.

2 Means in a row not sharing a common letter differ $(p<0.05)$.

${ }^{3} \mathrm{BLSD}=0.02$.

sity and the influence of past history of domestic livestock grazing, location, and time of defoliation on growth and development of a native perennial grass, Idaho fescue. Previous research indicated that Idaho fescue has the ability to develop ecotypes in relatively local areas in response to environmental conditions (Doescher 1983, Doescher et al. 1985). Tisdale (1961) found differences in growth of Idaho fescue that had been collected from 18 locations throughout most of its range in the western United States, including collections from eastern and central Oregon. For the central Oregon collection, he found average basal diameter and culm height were greater than for most of the remaining collections, while its date of first anthesis was one of the latest. Plants from eastern Oregon were noted for their very short culm height and low degree of leaf glaucousness (Tisdale 1961 and pers. comm.). Our

results were consistent with these observations.

The consistent lack of interaction between collection and defoliation treatment indicates that grazing history did not affect the way in which Idaho fescue responds to defoliation. There were, however, some differences between protected and grazed collections at central Oregon in terms of plant height and annual relative growth. This suggests a morphological dominance that is more adapted to herbivory may have occurred.

While the eastern Oregon exclosure plants have been protected from grazing for 52 years, before that time the site was heavily grazed. These plants, therefore, may not represent the full array of genotypic material that was present before the onset of grazing livestock in this area. The collection from the protected area in central Oregon, C-P, does represent a site unique in its historical lack of excessive grazing by livestock (Driscoll 1964). Although having smaller average basal area than the grazed collections in 1990, this collection (C-P) had greater height and relative growth than all of the grazed collections, even with defoliation.

Grazing history had no consistent influence on collection response to defoliation, but patterns of relative annual production in response to defoliation of all collections varied at eastern Oregon in 1990 and both locations in 1991. For the central Oregon population, total annual production was highest for the boot to anthesis defoliation treatment in 1991, while at eastern Oregon total annual production was highest for anthesis defoliation treatment in 1990 and for anthesis defoliated and undefoliated plants in 1991. These responses to defoliation suggest that Idaho fescue as a species may not as intolerant of grazing as previously believed (Young 1943). Research conducted by Caldwell et al. (1981), McNaughton (1979, 1984) and Detling and Painter (1983) indicated that a major physiological factor enabling certain grass species to tolerate heavy levels of herbivory is their ability to regrow rapidly following severe defoliation. Unlike bluebunch wheatgrass (Agropyron spicatum (Pursch.) Scribn. \& Smith), which has poor regrowth characteristics following heavy defoliation (Caldwell et al. 1981), Idaho fescue recovered well following defoliation.

Our results suggest that overcompensation as defined by Belsky (1986) (i.e., cumulative total dry weight, including removed tissue, 